\title{
Transatlantica
}

Revue d'études américaines. American Studies Journal

1 | 2021

Line Breaks in America: the Odds and Ends of Poetry

\section{Line Breaths in Allen Ginsberg's Poetry}

\section{Anna Aublet}

\section{(2) OpenEdition}

\section{Journals}

Electronic version

URL: https://journals.openedition.org/transatlantica/17094

DOI: 10.4000/transatlantica. 17094

ISSN: $1765-2766$

\section{Publisher}

Association française d'Etudes Américaines (AFEA)

\section{Electronic reference}

Anna Aublet, "Line Breaths in Allen Ginsberg's Poetry", Transatlantica [Online], 1 | 2021, Online since 01 July 2021, connection on 01 February 2023. URL: http://journals.openedition.org/transatlantica/ 17094 ; DOI: https://doi.org/10.4000/transatlantica.17094

This text was automatically generated on 1 February 2023.

\section{cc) (i) (9)}

Creative Commons - Attribution-NonCommercial-NoDerivatives 4.0 International - CC BY-NC-ND 4.0 https://creativecommons.org/licenses/by-nc-nd/4.0/ 


\title{
Line Breaths in Allen Ginsberg's Poetry
}

\author{
Anna Aublet
}

There are forms that are figurative to me, and if
they develop into a figurative image it's all right,
I don't have the feeling that something has to be
completely non associative... I think that if you
use long lines, they become-what could they be?
The only thing they could be is either highways
or architecture or bridges (Sylvester 7).

Painter Franz Kline's ${ }^{1}$ comparison of the long lines drawn on the canvas to "highways, architecture or bridges" is particularly fitting when studying Beat poet Allen Ginsberg's verse: "the highway across America" ("Howl," 2013 141), "Gray stone Empire State" ("Bayonne Entering NYC," 2013 428), or "Brooklyn Bridge's skeined dim in modern mist" ("Hospital Window," 2013 642), are all recurring urban shapes that line out his poetry. Ginsberg's long lines thus take on a calligramatic turn as they slither across the page, forming a chaotic criss-cross mapping out his many wanderings across the continent as well as the looming shapes of "Wall street islands of skyscraper black jagged in Sabbath quietness" ("Waking in New York," 2013 349). In the introduction to his Collected Poems 1947-1980, Ginsberg depicts the long roads travelled in his journeys, each collection of poems keeping the trace of his repeated line crossing, whether physical, moral or spiritual:

Cross-country Auto Poesy chronicle starts 1965 at Northwest border (The Fall of America), continues through Wichita vortex East (Planet News), recrosses U.S.A. Oakland to New York (Iron Horse) and tarries 1966 East, returns via Chicago North of vortex 1967, and comes back through Northwest passage 1969 (The Fall of America) (Ginsberg, 2013 5).

Reflecting upon his poetic art in "Improvised Poetics," the poet stated: "The question is how to figure out where to break the line" (1980 29). Ginsberg strove to figure out where to deviate from the guiding lines that William Carlos Williams and the modernists had drawn before him, and subsequently where to end his own line to give 
way to the next. One of the answers he provides is that the line breaks "when the thought breaks" (29) because "the mind-breaks that you go through in composing are the natural speech pauses too: after all, natural speech pauses indicate mind-breaks" (29). The answer may not seem completely satisfying, yet it emphasizes the importance of "natural speech rhythm" for the poet and his desire to remain as close as possible to spoken discourse. Ginsberg would have kept Williams's lesson in mind and transposed it, refashioning it to fit a new poetic and political agenda: "One must not slip back into the ruts rhyme and inversion of phrase. Let speech be the rule" (quoted in Wagner 136). Ginsberg might also have taken "the rule" to mean the measuring device guiding the length of his lines. Using the poem "Howl" as anchor point, this paper will also call upon a few other poems to emphasize the evolution of Ginsberg's poetic line through time. If Ginsberg followed many of the modernists' guidelines on verse, the length of his lines is also what sets him apart from them. This deviation thus takes on a poetic as well as a political turn. This paper intends to allow the reader to interpret the poet's long verse as a political line, a direction given to a new generation of poets and artists breaking free from the modernist heritage. This first analysis will lead us to reflect on the complex syntactical and rhythmical mechanisms at stake in Ginsberg's long line, whether silent or spoken: the verses of "Howl" are not as "natural" as the poet contends; they create a prolific network of significations that this paper shall attempt to analyse. Finally, the weight Ginsberg puts on vocalizing his poems is key to understanding his long lines and their effect on the reader or audience. The presence of the audience conditions the very act of writing.

\section{Breaking the Lineage}

3 An avid reader of Ezra Pound and William Carlos Williams, Ginsberg often acknowledged his modernist heritage, which he consistently subdued, converted and transformed as he wove it into his own verse. He once wrote about his poem "Howl": "the imagery often consists of 1920 s W.C.W. imagistically observed detail collapsed together by interior logic-i.e., 'hydrogen jukebox,"' Apollinaire, Whitman, Lorca. But not automatic surrealism. Knowledge of Haiku and ellipse is crucial" (Morgan 295). Lexical combinations such as "unshaven room," "ashcan rantings," "eyeball kicks," "sexless hydrogen," "hydrogen jukebox," "basement hungover," "tubercular sky" (Ginsberg, 2013 134-139) come to form impactful semantic entities and precipitate the reader into the underground, subterranean world that the poem depicts. Though the imagist influence in these associations is not as manifest as Ginsberg contends, the poet does follow Pound's indictment to "make it new," creating new semantic units from common and simple words-"new contours suggested by old words" (Williams 5). The eye witness of the opening line, "I saw the best minds of my generation destroyed by madness" (Ginsberg, 2013 134), guides the reader through a gruelling descent into Dante's inferno paced by the anaphora "who" which gradually effaces the initial "I" to give way to pure, unfiltered experience. The long verse's maze stretches like the railway line leading from Battery Park to the Bronx. The idiosyncratic juxtapositions dilate the verse and increase the pulse of the poem, thus leaving the reader panting. If the poem unfolds from the initial "I" observing the others ("who"), the first person gradually returns to the community, and the emergence of "we" ("O victory forget your underwear we're free" [2013 141, my italics]), at the very end of the poem, comes to 
index the final inclusivity. The reader is invited to share the same marginal space as the outcasts depicted in the poem, where the "I" had first removed himself:

who chained themselves to subways for the endless ride from Battery to holy Bronx on benzedrine until the noise of wheels and children brought them down shuddering mouth-wracked and battered bleak of brain all drained of brilliance in the drear light of Zoo,

who sank all night in submarine light of Bickford's floated out and sat through the stale beer afternoon in desolate Fugazzi's, listening to the crack of doom on the hydrogen jukebox,

who talked continuously seventy hours from park to pad to bar to Bellevue to museum to the Brooklyn Bridge. (2013 134-135)

The highly expressive poetic arrangement of "Howl" urges the reader to take part in the experience. Ginsberg's reading of the poem at the Six Gallery in San Francisco on October 71955 intensifies the poem's evocative powers: it gives a voice to a generation roaming the city tunnels. The poet's passionate way of reading articulates the wanderings of the "angelheaded hipsters" banned from social institutions and attempts to reinstitute and rehabilitate their humanity through poetry. The poem strives to share the experience of the outcasts.

If Ginsberg's first poems are suffused with romantic and modernist influences such as Blake, Keats as well as Pound, Williams or T.S. Eliot, some of them already reveal the political viewpoints of the younger poet. In "A meaningless institution," a poem composed in 1948 and formally closer to the verse of his British masters, Ginsberg already inscribes his lyrical and poetic "I":

I was given my bedding and a bunk

in an enormous ward

surrounded by hundreds of weeping,

decaying men and women. (2013 23)

6 At first, the poet positions himself above the community of patients ("I sat on my bunk, three tiers up / next to the ceiling, / looking down the gray aisles." [2013 23]) to ultimately come down and re-join the others "in search of a toilet" (2013 23). The isolated "I" returns to the community of outcasts and the final bathos (the poet wandering the corridors for a bathroom) reverses the romantic solitary walk. The Beat poet, still imbued with romantic poetry, barely freed from the modernist influence of Eliot, Pound and Williams, creates a new poetic measure and redefines the epic poem. In this early poem, the relationship between the lyrical "I" and the "best minds" of "Howl," "destroyed by madness," is already ghostly present. The poem works like the "meaningless institution" it depicts: it follows formal rules in order to reveal their sterility. The four quatrains of the poem encapsulate the poetic and political commitment of the poet by describing the infertility of institutional and poetic structures which hold the subjects and poets captive. If the long line is still associated with Ginsberg's poetry, the poet keeps coming back to rhyming patterns and shorter lines. His poetry is the result of a quest for balance between innovation and the renewal of ancient structures. "Howl," for instance, is an amplification and innovation on Whitman's line, haikus, and biblical verse. The formal emancipation is only partial. I argue that the renewal of the poetic structure, if any, occurs mostly in the corporeal and vocal commitment of the poet, something for Ginsberg that was linked with his political engagement and determined the length of his line. 
7 In his essay entitled "Transports de la liberté," Jacques Rancière raises the essential question of the relationship between "the modern position of the poetic word and that of political subjectivity" (Rancière 87, my translation). Ginsberg's quest for a new metrical form and emancipation was indeed a political matter: "the old canons, the ones that distinguished between poetic genres, their specific rules and their respective dignity were undeniably political" (Rancière 88 ). The new political experiences in which Ginsberg partook, such as the sit-ins and be-ins happening in San Francisco, would thus be linked to the search for a new poetic canon. The corporeal implication of street theatre and new physical forms of protestation helped to free the "lyrical subject from the old poetic and political structure" (Rancière 88). The advent of "protest poetry" coincided with a profound desire for poetic and political renewal. In the fall of 1965, the Vietnam Day Committee organized a march and a big political rally. As the protesters were preparing for a confrontation with the Hell's Angels (Schumacher 452-453), Ginsberg devised his own project entitled "How to Make a March / Spectacle." The poet gave out leaflets explaining his strategy. The idea was to demonstrate the theatricality of any political activity, even a freedom ride:

It could be seen as theater, as almost all political activity was. And given the situation, the best kind of theater would manifest the Peace that we were protesting. Pro-test being 'pro-attestation', testimony in favor of something. So if we were going to be a peace-protest march, then we should have to be peaceful, and being peaceful took skillful means under such anxious circumstances. (in Schumacher 453)

8 Conversely, public readings of the poem "America" sound like political rallies. The recordings stage the thin line separating poetic performance and political demonstration.

9 The counter-culture's yearning for freedom finds a formal expression in the poem. Ginsberg's long line, an elaboration on Walt Whitman's free verse, is the product and illustration of a spontaneous structure. The long line acts as a be-in participant, a freedom rider, a solitary hobo, digging its own track and ploughing its way through old canons. The poem "Howl," a cry for freedom, is an experiment in this new formal means of emancipation, as Eliot Katz explains: "as the lines continually refuse to stop at the right-hand margin of the page, they imply a strenuous effort to free the poetic line, and by extension the culture at large, from restrictive boundaries" (Katz 52). As early as 1949 , Ginsberg was putting his long line to the test in his poem "Paterson." Published in his first collection Empty Mirror: Gates of Wrath (1947-1952), the poem is framed by Williamsian poems composed of short lines, some of them almost objectivist, such as "The Bricklayer's Lunch Hour." The long line of "Paterson" however flows from line to line, overstepping any syntactical or lexical obstacle it may encounter. The length of the lines coincides with the length of grammatical clauses following the stream and rhythm of the poet's strenuous wanderings across the continent to his own "Golgotha in the Rockies" (2013 43), a cross on his back. Ginsberg argued that arranging his lines was "a little bit like diagramming a sentence, you know, the old syntactical method of making a little platform and you put the subject, verb and object on it and hang adjectives and adverbial clauses down" (Ginsberg, 1980 19).

streetcorner Evangel in front of City Hall, surrounded by statues of agonized lions, with a mouthful of shit, and the hair rising on my scalp,

screaming and dancing in praise of Eternity annihilating the sidewalk, annihilating reality,

screaming and dancing against the orchestra in the destructible ballroom of the 
world,

blood streaming from my belly and shoulders

flooding the city with its hideous ecstasy, rolling over the pavements and highways

by the bayoux and forests and derricks leaving my flesh and my bones hanging on

the trees. ("Paterson" ; Ginsberg 2013 48-49)

As he roams the cities of the country in his quest for freedom, the poet designs a new structure, synonymous with a renewed poetic and political independence. The long line enables him to free himself from the shackles of an unyielding individualistic society, which he associates with mainstream culture. He comes to give a new impetus to the poem and create an underground network.

11 This type of verse is also a way for the Beat poet to emancipate himself from Williams who wrote the introduction to this first collection of poems and advised him in a letter dated May 24, 1952 to "cut [his] table contents by half or even more drastically. You should leave out ALL the early stuff. ALL the rhyme. The book would then emerge lean, trimmed for action, for it is action which is demanded at this date" (Allen Ginsberg Papers box 14 folder $22 \mathrm{~ms} \# 0487$ ). The modernist poet expressed his thoughts somewhat harshly on the matter to Walter Sutton in the following words: "I am not thoroughly satisfied with what he has done. I have told him-I mean I am disgusted with him and his long lines" (Sutton 324). For Williams, a more fixed form, such as his own triadic verse, was not necessarily conservative, and free verse should not be inescapably associated with a revolutionary ideology. Free verse was already a rather "traditional" form when Ginsberg started writing his own poetry. One should rather try and transcend this binary Manichaeism, as Abigail Lang explains about Louis Zukofsky: "if the forms are ideological, their meaning shifts depending on the context" (Lang 17, my translation) For Ginsberg, the long free line falls in, nevertheless, with a new context, the result of a long endless journey. The conclusion to "Paterson," quoted above, ${ }^{2}$ evokes the lynching of black people and the Jim Crow laws in the South of the United States, thus alluding to one of the main causes defended by the poet and his friends in the counter-culture: the Civil Rights Acts of 1964, finally putting an end to segregation, fifteen years after the composition of the poem. The long lines of "Paterson" are the remaining furrows of a long, arduous historical and political march. They are also a way for the poet to delay the relief of the final revelation.

\section{The Underground-Railway Poetic Lines}

The long lines trace across the page the poet's long and strenuous journeys on the road, but they also create a rhizomatic underground structure and set of significance. In Allen Ginsberg's work, the underground may take the shape of nuclear bunkers, shelters or pantries for those preparing for a third world war in the midst of the Cold War. The underground is not nature's creation but man's construction. The subterranean world the poet depicts also appears to be an untapped lexical ore: a place to explore the vagabond idiosyncrasies of the American tongue by exhuming what Ginsberg calls the "archives of the underground" (2000 382). In his foreword to "Howl," Williams warns the readers that Ginsberg is summoning them to follow on a new variation of the descent into hell. The poem inaugurates a new Rimbaldian season in hell whose underground tentacles conjure up Dante's monsters as well as Williams's collection of poems entitled Kora in Hell (1920). If the lexical combinations display a powerful and vivid intensity, the poem remains abstruse and hermetic at times. As a 
matter of fact, the sinuous syntax oscillating between parataxis and hypotaxis largely accounts for this opacity:

who were burned alive in their innocent flannel suits on Madison Avenue amid blasts of leaden verse \& the tanked-up clatter of the iron regiments of fashion \& the nitroglycerine shrieks of the fairies of advertisement \& the mustard gas of sinister intelligent editors, or were run down by the drunken taxicabs of Absolute Reality, [...]

who sang out of their windows in despair, fell out of the subway window, jumped in the filthy Passaic, leaped on negroes, cried all over the street, danced on broken wineglasses barefoot smashed phonograph records of nostalgic European 1930s German jazz finished the whiskey and threw up groaning into the bloody toilet, moans in their ears and the blast of colossal steamwhistles, (2013 137)

How does a poem, which sometimes verges on silence and other times on pure noise, still succeed in conveying meaning to its readers? Jean-Claude Beaune argued that "Within these silences, these absences, the vagabond, the loner are thrusting their slightest Being" (Beaune 123, my translation) suggesting that the staggering gaps of communication caused by cries and silences are related to repetition, a recurring device in the poem (especially the use of anaphors): "It is possible to transform repetition, an essential component of pedagogy, into monotonous psalmody, superior mechanics: the individual then approaches ecstasy and assimilates with a transcending force or a magical power" (Beaune 123). In the case of "Howl" however, the "mechanics" of the poem, its anaphors-"who" in the first section, "Moloch" in the second, and "I'm with you in Rockland" in the third-do not seem to erase "the meaning of the message," as Beaune asserts. It would be too simplistic to state that "there is no more exchange, no more communication" within the poem, or that its language has "become a well-regulated machine, an automaton of sorts" (Beaune 123) as the anaphora is not so much the place where a new line starts as the locus where the line breaks. The anaphora is a symbolic margin, an empty space after the break; or, in Ginsberg's words: "the margin provides the anaphora" (1980 51) and is thus never really established as an automated device. Ginsberg attempts to palliate the monotony of his psalmody and the mechanics of repetition thanks to a more spontaneous counter-movement. The anaphora is never set as a stable system and the poet proceeds to the constant disruption of the very mechanics he has put in place. Like the society he criticizes and its "machinery of night" (2013 134), he introduces error even as he creates the system that has caused it. The poet lets us hear the "catatonic piano" (2013 141) which is alluded to in the second part and gives rhythm to the pingpong table of the psychiatric hospital "resting in catatonia" (2013 138). The long breaths of the first part are followed by the outpouring shouts of the second "Moloch! Solitude! Filth! Ugliness! Ashcans and unobtainable dollars! Children screaming under the stairway!" (2013 139). These exclamations come to answer the question raised in the first part formulated by Gregory Stephenson as follows: "To what merciless, cold, blind idol were the 'angelheaded' of section one given in sacrifice?" (Stephenson 54-55). Bordering on coprolalia and neurological syndrome in the second section, the poem moves on to a clear and organized discourse in the third. The part of the poem devoted to the mechanisms of society is the only one to develop a true "catatonic" mode, reminiscent of mental patients in their hospital cell: "A lot of these forms developed out of an extreme rhapsodic wail I once heard in a madhouse" (Ginsberg, 2000231 ). This section is also essentially composed of nominal sentences with very few conjugated verbs, emphasizing the poet's revulsion, verbless, before the monstrous 
laws of Moloch. The first and last sections use a more complex yet sometimes faulty syntax. The poet develops anaphoric subordinate clauses in "who" and "where," whereas the Moloch jeremiad is only a series of paratactic superimpositions. Unexpected cuts, discordant chords, unintelligible noises and ecstatic silences all punctuate the poem and prevent the system from truly settling. The poem does provide some "sense" for the reader: why attempt to censor it otherwise? How to explain its posterity? The constant sway, the oscillation between the two strategies delineates a gap through which a meaning can emerge. The poem, even as it challenges one system, creates an alternative one left for the reader to comprehend. And careful to introduce ordinary words, the poet greases the gears with the rhythm of the long lines in harmony with what he somewhat flamboyantly called his "Hebraic-Melvillean bardic breath" (Ginsberg, 2000 229). Ginsberg even seems at times to have some difficulty departing from smooth, correct grammar and ultimately sticks to a rather consistent standard syntax. For instance, in the following excerpt, he attempts to erase the commas from the clause to eventually bring them back at the end of the sentence:

danced on broken wineglasses barefoot smashed phonograph records of nostalgic European 1930s German jazz finished the whiskey and threw up groaning into the

bloody toilet, moans in their ears and the blast of colossal steamwhistles, (2013 137)

The reader has to fill in the gaps left by the deletion of commas. At this point in the poem the system has already been established and it therefore appears logical to place the commas before each verb to separate each process. The mechanics are integrated by the reader who has no difficulty reintroducing the original punctuation of the sentence. The absence of commas contributes nevertheless to unsettling the operating mechanics in the first part of the clause, where commas serve as a borderline between each action: "who sang out of their windows in despair, fell out of the subway window, jumped in the filthy Passaic, leaped on negroes, cried all over the street, danced on broken wineglasses" (2013 137). Most of all, these "lapses" foster and encourage the systematic confrontation of words. The blanks participate in the same process, as does the creative compound "hydrogen jukebox" already mentioned. The adjective "barefoot," if it seems at first to qualify the individual who "danced on broken wineglass," also introduces "smashed photographs." Otherwise, its logical place in the cognitive process would have been adverbial and it would have taken its place after "danced": "danced barefoot on broken wineglass" would have been proper, had the clause been followed by a comma. Here however, the foot, bloody from having danced on splinters of glass, is smashing the old albums, thus reducing nostalgic German jazz of the 1930s to silence: "nostalgic European 1930s German jazz finished." Here again, "finished" is both the past participle and the preterit for the following action "finished the whiskey." Images are juxtaposing and interlocking, they brush against one another to create meaning. To Allen Ginsberg, this hobbling syntax was the poetic articulation of Charlie Chaplin's stumbling tread: "making awkward combinations like Charlie Chaplin's walk" (Ginsberg, 2000 229). The meaning of these "awkward combinations" is not always controlled by the poet: it is the off-chance union of sense and nonsense that organizes a chaotic system. The text thus digs out subterranean and rhizomatic networks and develops a peculiar grammar. Although well-regulated, the syntactic chaos reinforces the expressiveness of the poem and bids the reader to experience the underground: "syntactic chaos, because of the centrality of syntax, provokes the deepest unease" (Lecercle 57): 
The poet thus invites us to a multiple, polyphonic and anamorphic reading of his poem whose syntax we have to reconstruct, or, as he explains in the poem, we need "to recreate the syntax and measure" (Ginsberg, 2013 138).

\title{
Line Breath: Writing and Speaking
}

\author{
Ideally each line of Howl is a single breath unit. \\ My breath is long-that's the measure, one \\ physical-mental inspiration of thought contained \\ in the elastic of breath (Ginsberg, 2000230 )
}

Another component of the expressiveness of the poem is its oral delivery by the poet himself. Public readings transform the spatio-temporal frame of the poem; it is henceforth liberated from the length of the paper sheet and the closed space of the collection to become what Vincent Broqua calls an authentic "third text" (Broqua 297). Ginsberg celebrates oral composition as a way to break free from what he considers to be the arbitrary limitation of the page which deprives breath of its duration ability: "[t]he main line of poetry is the breath, not the page" (Ginsberg, 1980 94).

Since it is written down on a page, silently, without everybody talking, the page determines the length of the line. It's an arbitrary thing-if I have a big enough notebook, it's a big long line, generally, because there's room for the hand to move freely across, and the mind to think freely in terms of, the long line. If it's a little pocket notebook that you stick in your back pocket then you tend to have smaller, choppier lines. (Ginsberg, 1980 18)

The poem "Howl" gives a clear and deep voice to the explorers of the periphery in their quest for a new meaning and renewed values. The recurring "dawn" (the negro streets at dawn" [2013 134], "cemetery dawns," [134]) infuses the poem with the desire for renewal of a whole generation. From this marginal space at daybreak, the poet testifies to his wretched condition and opens his poem stating: "I saw" (134). Once uttered onstage by Ginsberg, the "I" is embodied and takes a corporeal form thus revealing the true orphic and prophetic powers of poetry. In this "auto poesy," 3 the "I" of the poetic voice matches the "I" of the man delivering his poem.

While it may seem self-evident, poetry performances involve a set of conventions, one of them being the poet standing onstage in front of an audience. It is however interesting to note that this configuration appears a few times within the poems themselves thanks to the presence of an attentive listener within the "narrative". The poem "Sunflower Sutra" provides a good example of this formal device: "Jack Kerouac sat beside me on a busted rusty iron pole, companion, we thought the same thoughts of the soul" (2013 146). Kerouac remains nonetheless a silent listener throughout the poem and the dialogism is only theoretical. The presence of an audience seems to act as a trigger for an inner dialogue rather than an actual conversation. Ginsberg's poems, most of them "written on the tongue" (2000 n.p.) ${ }^{4}$ have the particularity of having been composed orally, at least at first. The monologism of the Beat poet is thus a theatrical dramatization. The poet exhibits himself in the poem even before doing so onstage. The vocal reading returns the poem to its original, "pre-scriptural" state. As Henri Meschonnic explains: "orality then becomes a possible characteristic of the written as well as the spoken word" (151, my translation). Accordingly, the written poem already possesses the rhythmic attributes of the spoken text insofar as an interlocutor is already present in the "narrative" of the poem. When Meschonnic states that "in his 
long sentence, Proust possesses his own orality, the subjectivity of his own rhythm," his analysis is remarkably applicable to Ginsberg's long line as a manifestation of his own physical and poetic subjectivity.

Ginsberg's poetry cannot easily be classified according to the categories of prose and poetry, of orality and literacy, a distinction whose simplicity Meschonnic condemns, calling it "the pseudo-wisdom of the binary" (168). This is another of Williams's claims, who kept underlining throughout his work the porosity between prose and poetry.

It is that prose and verse are both writing, both a matter of words and an interrelation between words for the purpose of exposition, or other better defined purpose of the art [...] I want to say that prose and verse are to me the same thing, that verse (as in Chaucer's tales) belongs with prose [...] Poetry does not have to be kept away from prose as Mr. Eliot might insist, it goes along with prose [...] (Williams, 1957 263)

In Ginsberg's work, another dichotomy is at stake, which Meschonnic identifies in the Bible as the "speaking/singing" dichotomy. This oscillation is very clear in some of Ginsberg's recordings such as The Lion for Real $(1997)^{5}$ in which the poet's reading takes on the form of Hebraic cantillation. The recording sounds like a ritual chanting and it often seems as though the poems themselves carried special tropes and accents for the poet to sing, like a Masoretic text. Each poem is read with a musical background especially composed for it, thus underlining the rhythm of the verse. The rhythm becomes apocalyptic in that it reveals a sort of implicit significance beyond the first semantic network woven by the poem. To Meschonnic, "all of those elements constitute the specific relationship between the rhythm and the poem" (168). Once again, Ginsberg's verse can be read as a further development of Williams's poetic art. Susan Churchill states that Williams wanted to "dispens[e] with rhyme altogether" and "us[e] only a rhythmic parallel [...] to mark the beginning and ending of the poem" (Churchill 107). In Williams's recordings, "it is fascinating to observe the complexity of his diction, cadenced and modulated as though the lines included a musical staff where the song would have been inscribed" (Aji 97, my translation). Literary history often considers Ginsberg's reading at the Six Gallery as one of the key oral performances on the American poetry stage, but we would have to go back to Williams who "had the oratory talent of the best American poet of today, trained under his tutelage" (Darras 4, my translation), to fully grasp its texture. Ginsberg explains the effect of Williams's reading of The Desert Music on him: "His record, William Carlos Williams Reading His Poems, a late Caedmon record of The Desert Music, which I first heard when Creeley played it to me, and Williams is so much in his actual speaking-man reality on that, he trembles on the verge of tears occasionally. And every word he pronounces is exactly meaningful there, like somebody talking. And it's like the greatest of-his practice has come to complete perfection almost-his intention of practice has finally come to a conclusion [...]" (Ginsberg, 1980 55).

21 "Howl" provides a good example of rhythmic and vocalic cantillation also called " $t e$ ' amim, whose appellation ta'am, meaning taste, oral and gustatory metaphor, supposes a mouthful of significance" (Meschonnic 378). This definition of ta'am recalls Williams's taste for words: "can you not see, can you not taste, can you not smell, can you not hear, can you not touch-words?" (Williams, 1971 159). Ginsberg howls his pain throughout the poem by the resounding use of [a], audible in [æ], [aI] and the [av] of "Howl." The very first line is particularly remarkable in that way: "[aI] saw the best m[ar]nds of $\mathrm{m}[\mathrm{ar}]$ generation, destroyed b[aI] m[æ]dness, starving, hysterical, naked" (2013 134), 
the next line also opening on the stressed [æ] of the trochaic "dragging." When metrics do not take into account poetic rhythm and let themselves be divided "according to binary categories," they are to Meschonnic "stifling" the universal "a-a-a" (461-462) of the poem. The cantillated rhythm thus narrows the gap between speaking subject, emotion and text, so much so that the "notion of howling, the notion of sound are reduced to metaphors of the relationship between rhythm and subject" (461). The end of the poem comes to seal the diphthong [ao] of the inaugural "Howl," with the repetitive use of the letter "o" developing [0] and [a] sounds as well as the diphthong [ou]:

I'm with you in $\mathrm{R}[\mathrm{\alpha}] \mathrm{ckland} /$ where we wake up electrified out of the c[ov]ma by our [ov]n s[o]ls' airplanes r[o]ring [ov]ver the roof they've c[a]me to $\mathrm{dr}[\alpha] \mathrm{p}$ angelic $b[\alpha] m b s$ the $h[\alpha] s p i t a l$ illuminates itself imaginary w[o]lls collapse [oo] skinny legions run outside [ov] starry-spangled sh[a]ck of mercy the eternal war is here $[00]$ victory forget your underwear we're free. (2013 141)

The repetition of "o" is shutting the loop as the poet comes back to his starting point, "the door of [his] cottage" (2013 141). The sign celebrates the cosmic continuum. In this final "o" the poet's breath dissolves, end of the desolation howl, "ow".

The condemnation of the failing social institutions that is immediately graspable in the poem slowly gives way to a religious symbolism, and the poem keeps binding political and religious discourses. The poet's political discourse, as described in the first part of this paper, is also related to rhythm and breath as he delivers a prosecution speech, which gradually morphs into a spiritual one, thus showing that poets, politicians and preachers all share language as a common material. Their speech is organized and its rhythm consistent with the message delivered. Though it may seem chaotic and accidental at times and appear as a string of words haphazardly chosen, Ginsberg's long line follows a pattern enabling him to develop a coherent discourse that is not so far removed from a ritual religious liturgy.

In the first part of the poem, the alarming assessment of the dysfunctional institutions gives way to a renewal symbolism by means of a purification process. Those "mad" people who are "starving" "naked" on the New York pavement (note the words designating flesh and blood people) are given angel wings and thus converted into angelic heroes on a visionary mode: "angelheaded hipsters burning for the ancient heavenly connection to the starry dynamo in the machinery of night" (2013 134). As the poem unfolds, Ginsberg sets up a ritual of purification by fire and light: the verb "burn" appears four times in the poem, doubled by the metaphor of the volcano and lava (2013 135); the recurring appearance of the verb "illuminate" along with "gleam" and the adjectives "starry," "radiant," "brilliant" together with nominal syntagms such as "lightning of the mind" or "king light of mind," "Harlem crowned with flame" all impose a spiritual and sacred dimension upon the poem. The poem weaves out a network of correspondence between political expression and religious discourse on a prophetic mode. The heroes of this Dantean Manhattan blend in with the starry sky to signify the immutability of the luminosity of spirit. The poet thus transforms the New York hipsters into the heroes of his poem: they become the prophets and guardians of an immortal message that will survive the apocalypse. This process of glorification and sanctification of the characters within the poem takes place gradually, following on a ritual pattern, a liturgical ceremonial whose various stages can easily be grasped. The poet's litany is indeed determined by narrative rules. If one omits the "Footnote to Howl," written afterwards as a conclusive "amen," the poem is divided into three parts. 
This organization seems to contradict the spontaneity of the oral squirt that the poet puts at the centre of his poetic composition: "first thought best thought" (2013 5). One may also recall the "speech spurts" (Ginsberg, 1980 51) mentioned by Ginsberg to qualify the composition of "Howl." How then does Ginsberg formally arrange these sudden flows and surges of language? I'd be tempted to conclude that it is the dissension, the constant dialogue between oral and written composition that articulates the poem. The incontrollable outpours of discourse are curbed and quelled by the ritual ceremonial of the writing process. In particular, the anaphors give the poem a formal structure by framing each "spurt" even as they trigger it. Besides, almost two third of the lines starting with "who" end on a monosyllable, such as "jazz," "war," "wall," "York," "night," to name only the very first ones. The spondaic stress pattern at the end of the lines acts as a restraining and steadying force for the oral stream of the poet. The poem is a religious litany insofar as the emotions of the poet are delivered and cadenced by anaphoric repetitions, the tripartite pattern and the use of the long line. These three formal characteristics define the creative faculties and expressive powers of rhythm.

By choosing to read Ginsberg's long line as something more than an attempt at composing a "lesser litany [...] something that has happened and so is news, like floods, fires, and other stimulating disasters" (Bloom 260), I hope to have shown the complex semantic matrix at work in the poems. If some poems may appear as mere solipsisms, they are redeemed by the highly powerful performances of their public readings, which kept reshaping the lines: "In Howl, there's that kind of run within the line; there are little breaks within the line, actually, depending on the humor in reading it, too." (Ginsberg 1980 25) The smooth and fluid quality of the long verses enables their constant motion and reshuffling, redefining with each reading-oral or silent-the contours of an ever changing society and its political, historical, spiritual and poetic lines.

\section{BIBLIOGRAPHY}

AJI, Hélène. Ezra Pound et William Carlos Williams: pour une poétique américaine. Paris: l'Harmattan, 2001.

BEAUNE, Jean-Claude. “Un détritus humain, le vagabond de l'entre-deux-monde." Cités, no. 1, 2000, p. 121-136.

BLOOM, Harold. Figures of Capable Imagination. New York: Seabury Press, 1976.

BROQUA, Vincent. "Le corps en lecture publique : surdramatisation, corps absent, corps et technologie (trois exemples nord-américains).” Dire la Poésie ? Nantes: Éditions nouvelles Cécile Defaut, 2015.

CHURCHILL, Suzanne W. The Little Magazine Others and the Renovation of Modern American Poetry. New York: Ashgate Publishing, 2006.

DARRAS, Jacques. Allen Ginsberg : La voix, le souffle. Paris: Jean-Michel Place, 2002. 
GINSBERG, Allen. Composed on the Tongue. San Francisco: Grey Fox Press, 1980.

GINSBERG, Allen. Collected Poems 1947-1997. New York: Harper Collins, 2013.

GINSBERG, Allen. Deliberate Prose: Selected Essays 1952-1995. New York: Harper Collins, 2000.

GINSBERG, Allen. The Allen Ginsberg Papers at Columbia University.

HOLIDAY, Billie. "Strange Fruit.” Strange Fruit. Commodore, 1939.

KATZ, Eliot. The Poetry and Politics of Allen Ginsberg. Charleston: Beatdom Books, 2016.

LANG, Abigail. "Politiques poétiques 'objectivistes', formes politiques et engagement poétique chez trois poètes 'objectivistes." Écriture et engagement aux États-Unis (1918-1939). Dir. Anne Ollivier-Mellios et Frédéric Sylvanise. Paris: Ophrys, 2010.

LECERCLE, Jean-Jacques. Philosophy of Nonsense. New York: Routledge, 1994.

MESCHONNIC, Henri. Politique du rythme, politique du sujet. Lagrasse: Verdier, 1995.

MORGAN, Bill, ed. The Letters of Allen Ginsberg. New York: Da Capo Press, 2008.

RANCIÈRE, Jacques. “Transports de la liberté.” La politique des poètes. Pourquoi des poètes en temps de détresse? Dir. Jacques Rancière. Paris: Albin Michel, 1992.

SCHUMACHER, Michael. Dharma Lion: A Critical Biography of Allen Ginsberg. New York: St. Martin's Press, 1992

STEPHENSON, Gregory. The Daybreak Boys. Carbondale: Southern Illinois University Press, 1990.

SUTTON, Walter. “A Visit with William Carlos Williams.” Minnesota Review I, Spring 1961, p. 324.

SYLVESTER, David. "Franz Kline 1910-1962: An Interview with David Sylvester." Living Arts, vol. 1, 1963.

WAGNER, Linda W. "William Carlos Williams: The Unity of His Art." The Bulletin of the Midwest Modern Language Association, 1969, vol. 2, Papers of the Midwest Modern Language Association, Number 1. Poetic Theory/Poetic Practice.

WILLIAMS, William Carlos. Imaginations (Kora in Hell, Spring and All, The Great American Novel, The Descent of Winter, A Novelette and other prose). New York: New Directions Publishing, 1971.

WILLIAMS, William Carlos. In the American Grain. New York: New Directions Publishing, 1956.

WILLIAMS, William Carlos. The Selected Letters of William Carlos Williams. New York: New Directions Publishing, 1957.

“The Lion for Real." Youtube, uploaded by Allen Ginsberg - topic, 30 July 2018, www.youtube.com/watch?v=Z5zRI_Nismc.

\section{NOTES}

1. Kline was a contemporary and friend of Frank O'Hara's, himself a friend of Ginsberg's.

2. The last line of the poem is an echo of Billie Holiday's 1939 song "Strange Fruit" in which she mentions the "strange fruits hanging from the poplar trees" (Holiday 0:51).

3. "Auto poesy" is a term often used by Ginsberg to refer to his poetry as both a poetry of the self and a vagabond poetry composed in a moving vehicle, automobile. See for instance Ginsberg, 20135.

4. "if it isn't written on the tongue, it's an essay." (Allen Ginsberg, epigraph to Deliberate Prose).

5. See for instance ("The Lion for Real", 0:00:00-0-05-44). 


\section{ABSTRACTS}

"I am not thoroughly satisfied with what he has done. I have told him-I mean I am disgusted with him and his long lines." As Williams delivers this message to his friend Walter Sutton, he condemns what he sees as Allen Ginsberg's inability to both carve and curb his verse. This article explores what occurs when the line won't break, when it goes on stubbornly wandering off the page. Ginsberg's long verse thus comes to index a break in his modernist lineage. It operates a departure from his modernist masters, Williams, Pound and Eliot. According to the Beat poet, the line should not be modelled after the length of the page, but rather attempt to break its delineations so as to return the poem to its original breath. These observations invite us to take a closer look at the long line as both a political and personal expression of the poet's journey on and off the page.

«I am not thoroughly satisfied with what he has done. I have told him-I mean I am disgusted with him and his long lines.» Lorsque Williams livre ces mots à son ami Walter Sutton, il condamne ce qu'il perçoit comme l'incapacité d'Allen Ginsberg à ciseler le vers, à en maîtriser son flot. Cet article examine ce qui se joue quand le vers résiste à la césure, quand il continue obstinément à tracer ses andains sur le papier. Le vers long de Ginsberg marque ainsi également une rupture dans l'héritage moderniste du poète, il vient briser la ligne tracée jusqu'ici par Williams, Eliot et Pound qu'il admirait tant. Pour le poète Beat, le vers ne doit pas répondre aux contraintes imposées par la page : il doit en transgresser les clôtures pour rendre au texte son souffle et son oralité. Cette réflexion nous invite ainsi à observer le vers long comme manifestation à la fois politique et personnelle des cheminements du poète sur la page, et audehors.

\section{INDEX}

Mots-clés: Allen Ginsberg, Beat generation, poésie, modernisme, William Carlos Williams, vers libre, Howl

Keywords: Allen Ginsberg, Beat generation, poetry, modernism, William Carlos Williams, free verse, Howl

\section{AUTHOR}

\section{ANNA AUBLET}

Université Paris Nanterre, CREA 